\title{
PHENOTYPIC PLASTICITY, COLONIAL FORMATION AND GROWTH CHARACTERS OF DESMODESMUS SPINOSUS AND SCENEDESMUS OBLIQUUS
}

\author{
Hesham M. Shafik \\ Botany Department, Faculty Of Science, Suez Canal University, Ismailia, Egypt. \\ Balaton Limnological Research Institute of the Hungarian, Academy of Science, \\ Tihany, Hungary
}

\begin{abstract}
:
Desmodesmus spinosus isolated from Lake Balaton (Hungary) and Scenedesmus obliquus isolated from the Nile water (Egypt) were studied in continuous cultures at $25^{\circ} \mathrm{C}$ and light intensity of $210 \mu \mathrm{mol} \mathrm{m} \mathrm{m}^{-2} \mathrm{~s}^{2}$ under different growth rates. At the steady states abundance, dry weight, chlorophyll-a, morphology and dimensions of cells were measured. The maximum growth rate was $2.78 \pm 10.1$ and $0.93 \pm 0.01 \mathrm{~d}^{-1}$ and the half saturation constant of growth was $7.18 \pm 11.0 \mu \mathrm{gP} 1^{-1}$ and $53.76 \pm 17.4 \mu \mathrm{g} \mathrm{N}^{-1}$ for $D$. spinosus and $S$ obliquus, respectively The cell volume and cell morphology varied with the growth rate. Cell size and chlorophyll content per cell or per cell volume increased with growth rate. Both species were isolated as a 4-celled coenobium and at time of isolation identified as D. spinosus and $\mathrm{S}$ obliquus. The 4-celled coenobia completely disappeared and only unicells algae were observed at low dilution rates. Rising of growth rate formed two-celled and/or 4-celled coenobia. At growth rates near or close to the maximum growth rate only four-celled coenobia (spiny in case of D. spinosus) were found in the culture vessels and they had form and dimensions the same as that found at the time of isolation. At low growth rates the morphological characters of formed unicells may overlap where the limiting nutrient concentration was very low. The plasticity of both species may depend on the growth and environmental conditions and it may cause misidentification for these species in natural samples.
\end{abstract}

Key words: Desmodesmus spinosis, growth, morphology, physiology, plasticity, Scenedesmus obliquus.

\section{Introduction}

Genus Scenedesmus has a worldwide distribution in fresh waters. It inhabits very different environments, ranging from the subtropical, oligotrophic waters to small hypertrophic temperate ponds. It inhabits lakes, rivers, reservoirs and many other habitats. These localities represent wide habitat diversity, in terms of both geomorphology and water chemistry, thus indicating a high level of ecophysiologycal adaptability of the genus. Two basic types would include those with fusiform or spindle shaped cells along with those possessing oblong-ovate cells, the latter are often spiny (Trainor, 1996). The genus Scenedesmus had been subdivided into two subgenera, Scenedesmus containing the non-spiny species and Desmodesmus containing the spined species (Kessler et al., 1997). Recently, An et al. (1999) divided genes Scenedesmus into two genera Scenedesmus and Desmodesmus according to the results of ITS-2 rDNA sequencing. Hegewald (2000) transferred many spices from genus Scenedesmus to the new genus Desmodesmus.

The morphological variability within the genus Scenedesmus has been well documented (e.g. Trainor et al., 1976; Trainor 1979, 1991, 1992 a \& b, 1993 a \& b, 1995 , 1996; Siver and Trainor, 1983; Egan and Trainor, 1989, Mladenov and Furnadzieeva 
1997, 1999). Also, there are many physiological experiments with several species of Scenedesmus (Sorokin and Krauss 1958; Rhee 1973, 1978; Mohammed et al., 1991; Shafik, 1985, 1991; Nalewajko et al., 1997; Ahlgren et al., 1998). Moreover, there are some studies on the effect of grazing on morphology of coenobium and spine formation (Lürling and Beekman 1999; Lürling and Van Donk, 1999, 2000). In spite of that many taxonomical problems still questionable.

Growth and specific character of cell and coenobial morphology of Desmodesmus spinosus (Chod.) Hegew. (Hegewald 2000), [earlier Scenedesmus spinosus (Chod.)] had not been described before under controlled cultures conditions, except the effect of temperature on growth rate in batch culture (Thibault and Couture, 1982) and growth and P uptake (Shafik and Herodek, 1991). While growth, cell division, cell structure, ecological parameter and morphological characters of Scenedesmus obliquus (Turpin) Kützing has well been investigated (e.g. Tezuka, 1977; Langowska \& Zawadzki 1979; Herewald,1982; Mohammed et al., 1991; Sancho et al., 1997; Pawlak \& Kopec 1998; Cepák \& Lukavský 1998 and Lürling 1999). The main diagnostic features of both species had been described and pictured by Hindák, 1990 and Uherkovich, 1995 as follow:

Desmodesmus spinosus: Coenobia 2-4-8-cells, but 8 cellsed coenobia mostely formed in cultures, straight to slightly curve, linear, with cells not alternated or alternated only slightly. Mucilage not formed. Cells cylindrical to longitudinally oval, outer cells slightly bent, ends rounded to slightly conical; dimensions: $6-9 \times 1.8-3 \mu \mathrm{m}$. Spinens at poles of outer cells long, equally in length; no bicaudate coenobia. Occasion one or more shourtely spine in the median part of outer cells at the poles of inner cells formed. Sometimes in cultures the main and additional spines are tooth-like and short. Or spines at the poles of inner cells are long.

Scenedesmus obliquus: The shape of cells is essentially fusiform to cylindrical, sometimes asymmetrical, often in the outer cells differentiated from inner ones. Coenobia may thus be compsed either of equal cells or outer cells are slightly lunately bent. If the cells of the coenobiaum are densely next to each other and not alternating, then the inner cells are fusiformly to cylindrical to cylindrical. Cells are narrowing toward the ends. sometimes they are shortly attenuated and sharply pointed, at other times bluntly pointed. Cell dimensions are 6-12-(22) x (1)-2-3-(17) $\mu \mathrm{m}$.

During growth process morphological, physiological and biochemical characteristics of the organisms are quickly changing, except for a relatively short period in the exponential growth phase. Therefore, continuous culture technique at different growth rates under steady state condition was used, where the characters of the growing organism are stabile. The effects of nitrogen or phosphorus limitation on growth, cell composition and cell morphology of two species belonging to the two genera were investigated.

\section{Materials and methods}

Two chlorococcal algae species used in this study were isolated and identified as Scenedesmus obliquus and Desmodesmus spinosus (earlier Scenedesmus spinosus). Scenedesmus obliquus was isolated from Nile water of Egypt and Desmodesmus spinosus was isolated form a water sample collected from Lake Balaton, Hungary. Both of them 
were isolated as a single four-celled coenobium. The purified strains have been grown and kept in a medium shows in table (1).

The algal strains were grown in continuous cultures using two identical chemostats of 2 -liters capacity. The chemostat apparatus had been described in detailed by Shafik et al. (1997). The culture vessels of the chemostats were immersed in a water bath at temperature of $24{ }^{\circ} \mathrm{C}$. The culture vessels were continuously illuminated from two sides by cool-white fluorescent tubes with an irradiance at the surface of the culture vessels of $210 \mu \mathrm{mol} . \mathrm{m}^{-2} \mathrm{~s}^{-1}$.

Table 1. The composition of medium $\left(\mathrm{mg} \mathrm{I}^{-1}\right)$ used in isolation, cultivation and growth of Scenedesmus obliquus and Desmodesmus spinosus.

\begin{tabular}{|l|c|c|c|}
\hline \multicolumn{1}{|c|}{ Nutrient } & Medium for isolation & P limited & N limited \\
\hline $\mathrm{K}_{2} \mathrm{HPO}_{4}$ & 31 & 0.31 & 31 \\
\hline $\mathrm{Ca}\left(\mathrm{NO}_{3}\right)_{2} \cdot 4 \mathrm{H}_{2} \mathrm{O}$ & 112 & 112 & 0.500 \\
\hline $\mathrm{Mg} \mathrm{SO}_{4} \cdot 7 \mathrm{H}_{2} \mathrm{O}$ & 50 & 50 & 50 \\
\hline $\mathrm{Na}_{2} \mathrm{CO}_{3}\left(\mathrm{H}_{2} \mathrm{O}\right)$ & 20 & 20 & 20 \\
\hline $\mathrm{Fe}_{\mathrm{EDTA}}$ & $10^{*}$ & $10^{*}$ & $10^{*}$ \\
\hline $\mathrm{H}_{3} \mathrm{BO}_{3}$ & 0.31 & 0.31 & 0.31 \\
\hline $\mathrm{Mn} \mathrm{Cl}_{2}$ & 0.25 & 0.25 & 0.25 \\
\hline $\mathrm{Na}_{2} \mathrm{MO}_{4} \cdot 2 \mathrm{H}_{2} \mathrm{O}$ & 0.003 & 0.003 & 0.003 \\
\hline $\mathrm{KI}$ & 0.003 & 0.003 & 0.003 \\
\hline $\mathrm{Zn} \mathrm{SO} \mathrm{SO}_{4} \cdot 7 \mathrm{H}_{2} \mathrm{O}$ & 0.028 & 0.028 & 0.028 \\
\hline $\mathrm{KI}^{\mathrm{Ni} \mathrm{SO}_{4} \cdot 7 \mathrm{H}_{2} \mathrm{O}}$ & 0.008 & 0.008 & 0.008 \\
\hline $\mathrm{Nu} \mathrm{SO}_{4} \cdot 5 \mathrm{H}_{2} \mathrm{O}$ & 0.014 & 0.014 & 0.014 \\
\hline $\mathrm{Co} \mathrm{Cl}_{2} \cdot 6 \mathrm{H}_{2} \mathrm{O}$ & 0.012 & 0.012 & 0.012 \\
\hline$\left(\mathrm{NH}_{4}\right)_{6} \mathrm{Mo}_{7} \mathrm{O}_{24}$ & 0.013 & 0.013 & 0.013 \\
\hline $3 \mathrm{Cd} \mathrm{SO}_{4} \cdot 8 \mathrm{H}_{2} \mathrm{O}$ & 0.008 & 0.008 & 0.008 \\
\hline $\mathrm{KBr}$ & 0.041 & 0.041 & 0.041 \\
\hline
\end{tabular}

$*=\mathrm{ml} \mathrm{l}^{-1}$ of $\left.\left.\operatorname{lnmol~FeCl}\right|_{3}\right|^{-1}+\operatorname{lnmol~HCl} 1^{-1}+\operatorname{lnmol~EDTA-Na} l^{-1}$

The first experiment was phosphorus limited by $300 \mu \mathrm{g} \mathrm{P} \cdot \mathrm{l}^{-1}$ and the second was nitrogen limited by $300 \mu \mathrm{g} \mathrm{N}^{-1}$ in the inflowing medium (see Table 1). After the cultures had reached a steady state [dilution rate $(D)=$ growth rate $(\mu)$ ] a definite volume of 120 $\mathrm{ml}$ from each culture was harvested for analysis. The analyses were run for three successive days. Afterward the dilution rate was set at a new higher value and the population was again allowed to reach the steady state. The cultures were reached the new steady state within two weeks.

At each steady state soluble reactive phosphorus (SRP) and nitrate-nitrogen in the culture vessels was measured. SRP was measured with the molybdate method (Murphy and Riley, 1962) Nitrate was determined via reduction to nitrite according to Elliott and Porter (1971).

Concentration of chlorophyll- $a$ was determined by extraction with boiling methanol according to Iwamura et al. (1970). The changing of the morphological features diagnostic mainly by microscopic examination. From each culture $20 \mathrm{ml}$ samples were preserved by Lugol's solution and stored in an ice-box $\left(4^{\circ} \mathrm{C}\right)$ until examination by Utermöhl's technique (1958). After at least 6 hours sedimentation the algal cells were counted and the cell volume were estimated from length and width measurements and geometric formulas, a minimum number of 50 cells per samples were measured using a video camera coupled with an inverted microscope.

Egypt. J. Phycol. 1, 2000. 
To determine the dry weight, $50 \mathrm{ml}$ of the culture was filtered on membrane filters (pore size $0.45 \mu \mathrm{m}$ ) of predetermined dry weight. The filters with the algae were dried at $105^{\circ} \mathrm{C}$ overnight, and then reweighted. The growth parameters were described according to Monod (1942) as a relationship between growth rate and the concentration of limiting substrate in the culture vessel:

$$
\mu=\mu_{\max } \frac{\mathrm{S}}{\mathrm{K}_{\mathrm{s}}+\mathrm{S}}
$$

Where, $\mu_{\max }$ is the maximum value of $\mu$, i.e. when $S$ is no longer limiting, $K_{\mathrm{s}}$ is the half saturation constant, numerically equal to the growth limiting substrate concentration at which, $\mu=1 / 2 \mu_{\max }$.

\section{Results}

\section{Growth and production rates}

In the case of D. spinosis which grown in $\mathrm{P}$-limited cultures (P concentration was $300 \mu \mathrm{g} \cdot \mathrm{I}^{-1}$ in the inflowing medium) the dilution rate was increased in 11 steps between 0.36 and $2.55 \mathrm{~d}^{-1}$. Cell number, dry weight and chlorophyll- $a$ content in the culture vessels decreased by one order of magnitude as a result of increasing of dilution rate.

The dry weight of cell had three phases where decreased between growth rates 0.36 and $0.81 \mathrm{~d}^{-1}$ then it was unchanged to growth rate of 1.38 then increased with growth rate. While, the chlorophyll- $a$ per cell increased with the dilution rate from 0.2 to 0.6 pg. $\operatorname{cell}^{-1}$ (Fig. 1). The chlorophyll- $a$ content was only $0.6 \%$ of the dry weight at the lowest dilution rate; then it increased up to $1.7 \%$ at the maximum dilution rate. The chlorophyll$a$ content calculated per cell volume $\left(\mu \mathrm{m}^{3}\right)$ was increased linearly with the growth rate (fg Chl-a $=2.453 \mu+11.306 ; \mathrm{R}^{2}=0.665$; Fig. 2 , a).

The production rate (Fig. 3 ) for both dry weight and chlorophyll- $a$ exponentially increased with growth rate where, pg dry wt cell ${ }^{-1} \mathrm{~d}^{-1}=6.879 \mathrm{e}^{1.00 \mu}$; and. pg Chl- $a$ cell $\mathrm{cos}^{-1} \mathrm{~d}^{-1}$ $=0.0685 \mathrm{e}^{1.262 \mu} ; \mathrm{R}^{2}=0.99$ and 0.97 for day weight and chlorophyll-a respectively.

In the case of $S$. obliquus, which had grown in $\mathrm{N}$-limited cultures (nitrate concentration was $5 \mathrm{mg}$ in the inflowing medium) the average dry weight was $33 \pm 4 \cdot \mathrm{pg}$ cell $^{-1}$ at all steady state. While the chlorophyll- $a$ content per cell increased from 0.08 to $0.29 \mathrm{pg} \mathrm{cell}^{-1}$ with growth rate (Fig. 1). The chlorophyll- $a$ content was only $0.2 \%$ of the dry weight at the lowest dilution rate; then it increased up to $1.2 \%$ near the maximum growth rate. The chlorophyll- $a$ content calculated per cell volume $\left(\mu \mathrm{m}^{3}\right)$ was increased linearly with the growth rate (fg Chl-a $=1.26 \mu+1.14 ; \mathrm{R}^{2}=0.953$; Fig. 2,b). The production rate (Fig. 3) was exponentially increased with the growth rate for both of dry weight and chlorophyll-a where, pg dry wt cell $^{-1} \mathrm{~d}^{-1}=6.3002 \mathrm{e}^{1.985 \mu}$; and. pg Chl- $a$ cell ${ }^{-1} \mathrm{~d}^{-1}$ $=0.0108 \mathrm{e}^{3.637 \mu} ; \mathrm{R}^{2}=0.96$ and 0.963 for day weight and chlorophyll- $a$ respectively. The maximum growth rate calculated by equation (1) was $2.78 \pm 0.1 \mathrm{~d}^{-1}$ and the $K_{s}$ was $7.18 \pm$ $1.0 \mu \mathrm{g} \mathrm{P} \mathrm{I}^{-1}$ for D. spinosus (Fig. 4). While the maximum growth rate was $0.95 \pm 0.01 \mathrm{~d}^{-1}$ and $K_{s}$ was $53.76 \pm 7.4 \mu \mathrm{gN} \mathrm{I}^{-1}$ for $S$. obliquus (Fig. 5). Figures (4\& 5) show the change of cell volume, cell morphology and colonial formation under different steady states. 

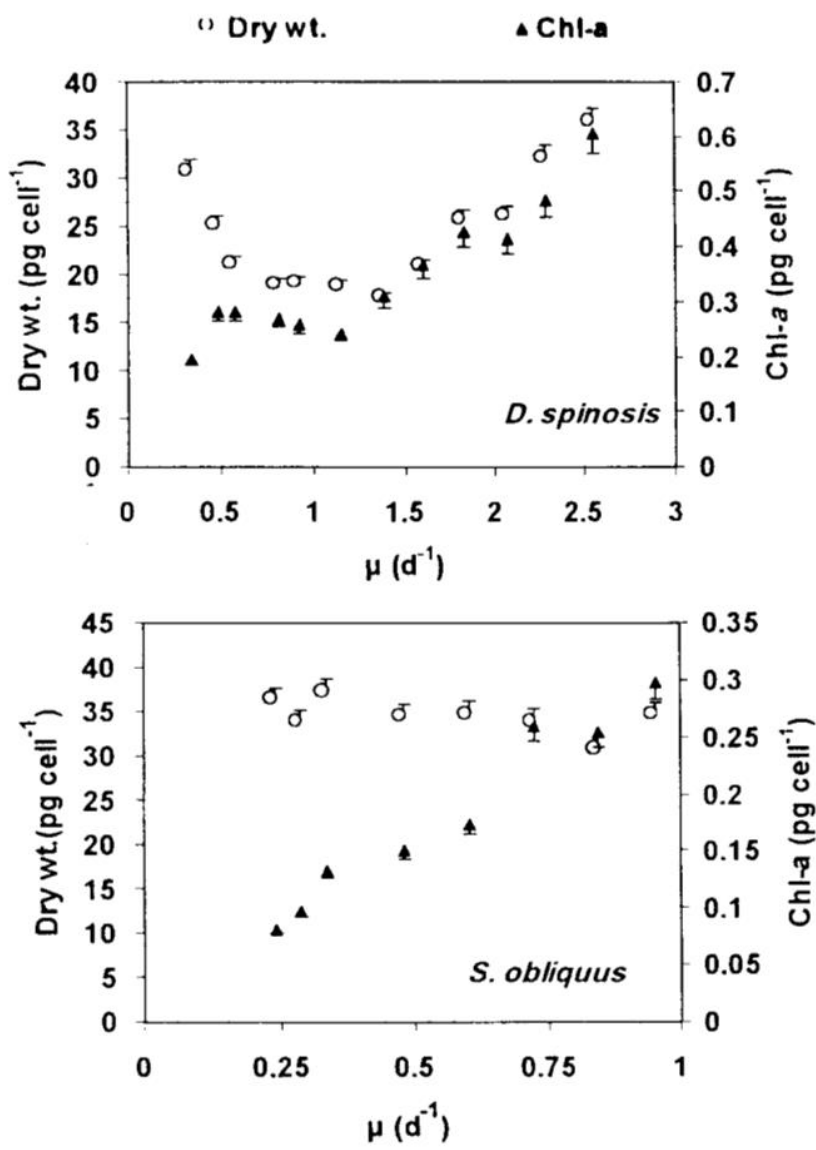

Fig. 1. Effect of growth rate on dry weight and chlorophyll- $a$ content per cell of $D$. spinosis and $S$. obliquus.
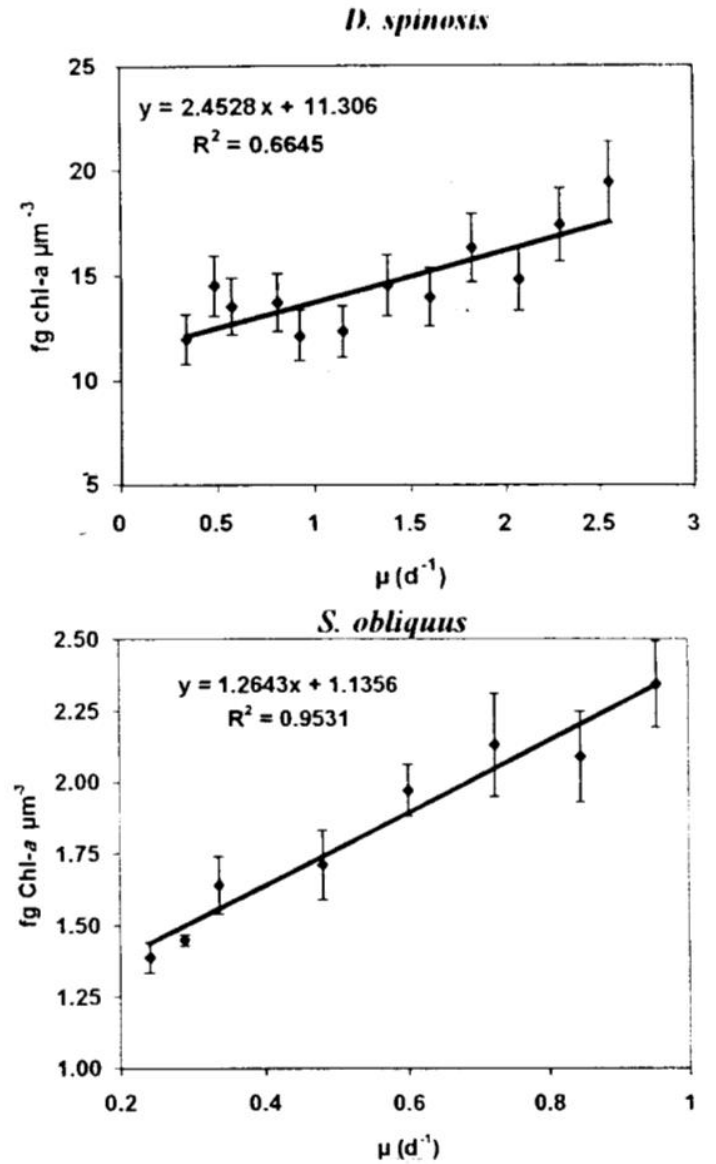

Fig. 2 (a \& b). Effect of growth rate on chlorophyll-a content per cell volume of $D$. spinosis and $S$. obliquus. 


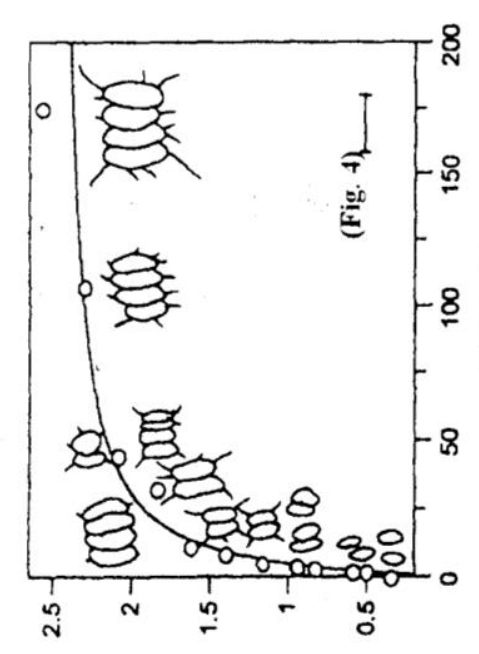

(tp) $\pi$

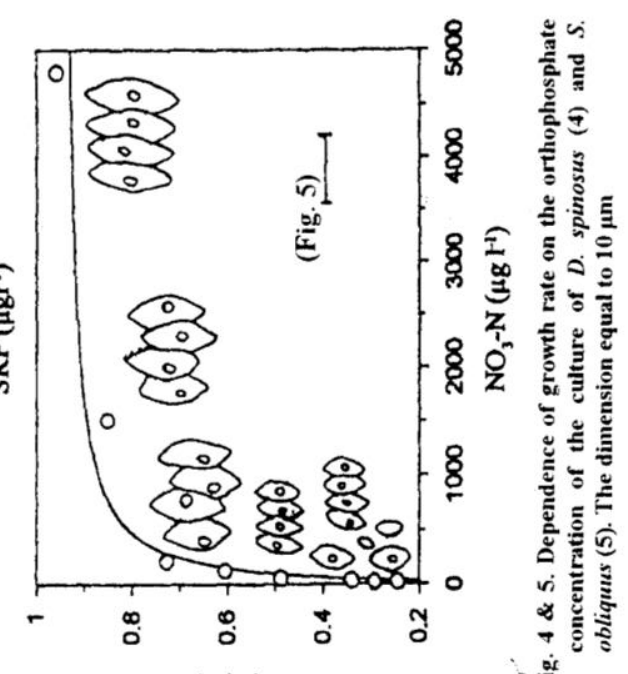

(1P) $\pi$

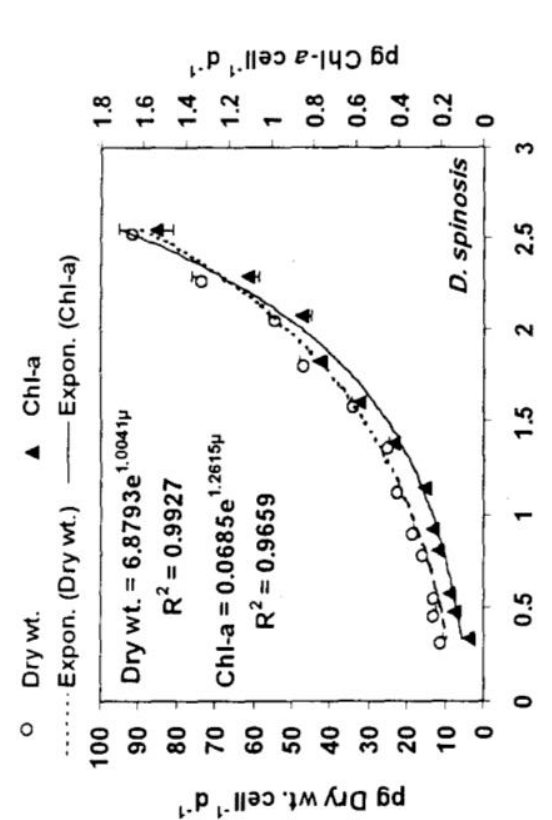

Egypt. J. Phycol. 1, 2000.

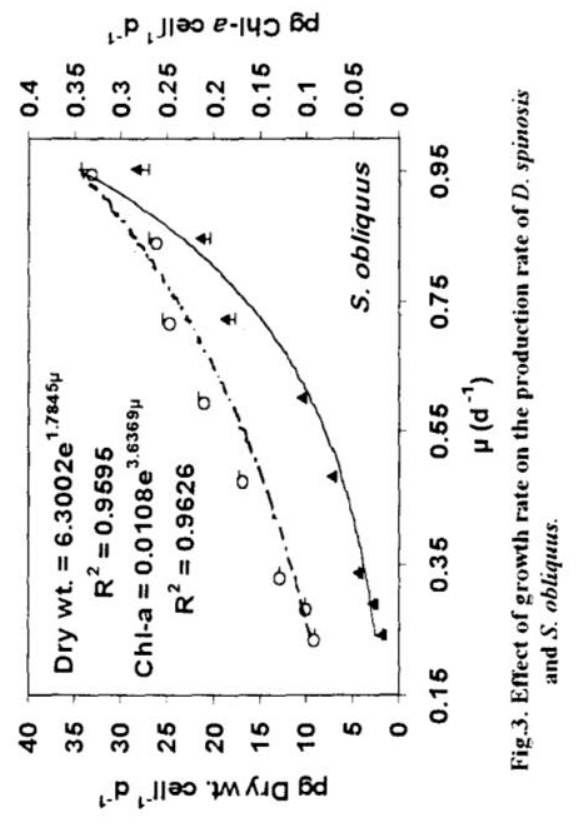

$-186-$ 


\section{Changes of cell dimensions and morphological features}

Table (2). shows the average measurements of the cell dimensions at different dilution rates of both species. The cell length increased with growth rate and the maximum cell lengths were gauged at the maximum dilution rate. One-way ANOVA on the mean cell length indicated a significant effect of growth rate $(\mathrm{F}=140.5 ; \mathrm{p}<<0.0001$ for D. spinosis and $\mathrm{F}=228.7 ; \mathrm{p}<<0.0001$ for $S$ obliquus). While the width of cells of $D$. spinosis was unchanged however that of $S$. obliquus slightly increased with growth rate. One-way ANOVA on the mean cell width indicated a significant effect $(F=31.1$; $\mathrm{p}<0.0001$ for $D$. spinosis and $\mathrm{F}=651.2 ; \mathrm{p}<<0.0001$ for $S$ obliquus). This reflects that the cell volume increased with growth rate in both species. One-way ANOVA on the mean cell volume indicated a significant effect $(\mathrm{F}=276.7 ; \mathrm{p}<<0.0001$ for $D$. spinosis and $\mathrm{F}=100.5 ; \mathrm{p}<<0.0001$ for $\mathrm{S}$ obliquus). The cell volume of $S$. obliquus was bigger than that of $D$. spinosis while the minimum cell volume is the half of the maximum in case of $D$. spinosis and less than half in case of $S$. obliquus.

Table 2. Length and width dimensions $\pm(\mathrm{SD} ;$ in $\mu \mathrm{m})$ and average cell volume $\left(\mu \mathrm{m}^{3}\right)$ of $(\mathrm{A}) D$. spinosis and (B) S. obliquu's at various growth rate at steady-state.

A

\begin{tabular}{|c|c|c|c|}
\hline$\mu\left(d^{-1}\right)$ & Length & Width & Cell volume \\
\hline 0.338 & $5.0(0.5)$ & $2.5(0.5)$ & 16.36 \\
0.481 & $5.5(0.6)$ & $2.6(0.4)$ & 19.47 \\
0.572 & $5.5(0.5)$ & $2.7(0.5)$ & 21.00 \\
0.806 & $6.0(0.4)$ & $2.5(0.5)$ & 19.64 \\
0.923 & $6.5(0.6)$ & $2.5(0.3)$ & 21.28 \\
1.144 & $6.0(0.7)$ & $2.5(0.3)$ & 19.64 \\
1.378 & $6.5(0.5)$ & $2.5(0.2)$ & 21.28 \\
1.599 & $8.0(0.3)$ & $2.5(0.2)$ & 26.19 \\
1.820 & $8.0(0.7)$ & $2.5(0.2)$ & 26.19 \\
2.067 & $8.5(0.9)$ & $2.5(0.5)$ & 27.82 \\
2.288 & $8.5(0.8)$ & $2.5(0.5)$ & 27.83 \\
2.548 & $9.5(0.7)$ & $2.5(0.5)$ & 31.10 \\
\hline
\end{tabular}

B

\begin{tabular}{|c|c|c|c|}
\hline$\mu\left(d^{-1}\right)$ & Length & Width & Cell volume \\
\hline 0.24 & $7.0(0.5)$ & $4.0(0.5)$ & 58.67 \\
0.288 & $8.0(0.6)$ & $4.0 .(0.35)$ & 67.05 \\
0.336 & $11.0(0.2)$ & $3.75(0.5)$ & 81.03 \\
0.48 & $10.5(0.3)$ & $4.0(0.5)$ & 88.00 \\
0.600 & $10.5(0.2)$ & $4.0(0.5)$ & 88.00 \\
0.722 & $11.5(0.7)$ & $4.5(0.3)$ & 121.98 \\
0.845 & $11.5(0.6)$ & $4.5(0.1)$ & 121.98 \\
0.953 & $12.0(0.8)$ & $4.5(0.5)$ & 127.29 \\
\hline
\end{tabular}

The changing of percentage of colonial presentation with growth rate is shown in Table 3. In case of $D$. spinosis at lower growth rates only unicells were found but the cell volume slightly rises (Table 2). Between growth rate of 0.806 and $1.800 \mathrm{~d}^{-1}$ the twocelled coenobia were dominated and at highest growth rates only four-celled coenobia were recorded. For the number of cells per colony in D. spinosis, the one-way ANOVA indicated a significant growth rate effect $(F=3.1 ; p=0.037)$. The spines only observed at growth rates higher than $0.923 \mathrm{~d}^{-1}$. At dilution rates lower than $1.144 \mathrm{~d}^{-1}$ the unicells or two-celled ceonobia were without spins, while all four-celled ceonobia, when found, have spines.

In case of $S$ obliquus only unicells and four-celled ceonobia observed and the unicelled ceonobia presented only at lower dilution rates and completely disappear at growth rates above $0.48 \mathrm{~d}^{-1}$. There are a coupled relationship between the number of cells per colony and the growth rate. A significant effect of growth rate was calculated $(F=$ $37.8 ; \mathrm{p}<<0.001$ ). This strain is not able to divided into 2-celled coenobia. 
Table 3. The percent phenotypic plasticity occurrence of (A) D. spinosis and (B) $S$. obliquus unicellular, 2-cells and 4-cells colonial under steady -state at different growth rate $=$ coenobia with spines

A

\begin{tabular}{|c|c|c|c|}
\hline$\mu(\mathrm{d}-1)$ & unicellular & 2-cells & 4-cells \\
\hline 0.338 & 100 & 0 & 0 \\
0.481 & 100 & 0 & 0 \\
0.572 & 100 & 0 & 0 \\
0.806 & 20 & 80 & 0 \\
0.923 & 15 & 85 & 0 \\
1.144 & 10 & $90^{*}$ & 0 \\
1.378 & 8 & $92^{*}$ & 0 \\
1.599 & 10 & $70^{*}$ & $20^{*}$ \\
1.82 & 7 & $67^{*}$ & $27^{*}$ \\
2.067 & 3 & $42^{*}$ & $55^{*}$ \\
2.288 & 0 & 0 & $100^{*}$ \\
2.548 & 0 & 0 & $100^{*}$ \\
\hline
\end{tabular}

\begin{tabular}{|c|c|c|c|}
\hline$\mu(\mathrm{d}-1)$ & unicellular & 2-cells & 4-cells \\
\hline 0.24 & 60 & 0 & 40 \\
0.288 & 55 & 0 & 45 \\
0.336 & 16 & 0 & 84 \\
0.48 & 7 & 0 & 93 \\
0.6 & 0 & 0 & 100 \\
0.7224 & 0 & 0 & 100 \\
0.8448 & 0 & 0 & 100 \\
0.9528 & 0 & 0 & 100 \\
\hline
\end{tabular}

\section{Discussion}

There is couple relationship between the physiological and morphological characteristic of phytoplankton organisms. In the case of Desmodesmus spinosis and Scenedesumus obliquus this relationship is quite clear.

According to continuous culture theory under steady state condition at least the physiological characters of the growing organism are stable. In this respect growth rate is the key of control. In the case of D. spinosis and under low growth rates $\left(<0.58 \mathrm{~d}^{-1}\right)$ small volume, unicells, nonspiny algae with low chlorophyll content were found. At dilution rates above $0.58 \mathrm{~d}^{-1}$ two-celled coenobia were frequently observed. At lower growth rates the limiting nutrient concentration is very low and dissolved nutrients must pass though the semi-permeable membrane into the cell. Thus, algal cells have to remain small with a favorable surface:volume ratio enabling efficient nutrient uptake. (Reynolds 1991). At higher growth rates higher concentration of dissolved nutrient is available therefore cell size, chlorophyll content per cell or per cell volume and production rate increased. Above growth rate of $1.38 \mathrm{~d}^{-1}$ four-celled colonies became dominant and the spines of the cells became longer. In the case of $S$. obliquus and under low growth rates the unicells were dominanted with low chlorophyll content. Two-celled coenobia have not formed at an growth rate this may distinguished of $S$. obliquus. Cepák and Lukavský (1998) reported that $S$. obliquus is not able to divide into 2-celled cocnobia. At growth rates higher than $0.48 \mathrm{~d}^{-1}$ only four-celled coenobia were observed. So, above this growth rate the chlorophyll content per cell and/or per cell volume were increased. It is well kwon that the half saturation constant is the concentration of limiting nutrient to which the response is that of theoretical maximum growth. The growth rates of 1.38 and $0.48 \mathrm{~d}^{-1}$ are closed to the half maximum growth rate of $D$ spinosis and $S$. ohliquus respectively. This means that below the half saturation constant not only the physiological state of cells but also the morphological features. The "ideal" cell morphology may be observed only when the algae grow at growth rates higher than the half-maximum ratc. Accordingly the appearance of algal cell of $D$. spinosis or $S$. oblicyus in their natural habitat as unicclls or two-celled coenobia may reflect unsuitable growth condition(s). And shows that the 
nutrient limitation affects not only cell size but also the morphological characteristics and colony formation of the algae.

Similar effects have been reported for other algae in batch cultures (e.g. TILMAN et al., 1976; VELDHUIS \& ADMIRAAL, 1987). Senedesmus sp. is most frequently found in nature as four-celled coenobia. I believe that the four-celled coenobia are found only when the algal cells grow under good conditions and the nutrient concentration is higher than that of the half of saturation constant. EGAN \& TRAINOR (1989); reported that the morphology and size of both cell and colony of genus Scenedesmus communis is highly effected by the conditions of growth. Many phenotypes have been demonstrated in the genus Scenedesmus (see, e.g., HINDÁK 1990). Our study revealed that in the case of $D$ spinosis and $S$. obliquus the same genotype (the algae isolated as one four-celled coenobia) might show many phenotypes depending on the growth rate. These changes in morphology, colony formation and cell size may cause misidentification for algae in natural water. Phynotypic plasticity refers to the ability of a single genotype to produce several phenotypes under fluctuating environmental conditions. Recent genetic and molecular studies have yielded crucial information about the mechanism of plasticity at the gene level (e.g. Guttenbrunner et al.,1994; Santoni et al., 1994). In order to realize how a variant phenotype is produced we must first understand that not all the genetic information contained in an individual is used at one time (Ridley 1996, Oliver 1996). This is, genes are turned on and off by the action of master switches following environmental shifts (Morales and Trainor 1999). This may explain by that the gene(s) responsible to the coenobia and spines formation is (are) turned on when cell quota exceeds a threshold value.

Siver and Trainor (1981, 1983), demonstrated that the unicell/colony transformation in Scenedesmus is independent of growth rate, but could be achieved by altering of chemical environment which may cause by grazer Daphnia (Lürling and Van Donk 2000). It is clearly that the nutrient concentrations in the culture vessels of chemostat are depending on growth rate and both genera may express considerable morphological variability even if the grazer is absent.

EPSTEIN \& ALLAOY (1967) showed that the chlorophyll- $a$ is more abundant in algae that are grown rapidly. FUHS et al (1972) stated that the chlorophyll-a content per cell was little affected by growth rate, whereas the amount of chlorophyll per unit cell volume changed significantly. In contrast, VYHNÁLEK (1990) in cyclostat did not find any relationship between chlorophyll- $a$ content of the algal biomass and the dilution rate of Chlamydomonas geitlerii. LATASA \& BERDALET (1994) suggested that pigment concentration more drastic effect by nitrogen metabolism than by phosphorous. In our experiment chlorophyll-a content per cell was more or less constant at lower growth rates, but above a growth rate corresponding to $1 / 2 \mu_{\max }$ it increased significantly. The increasing of chlorophyll content per cell; above this dilution rate may be a result of the increasing of cell volume and indicating that the phosphorus content per cells controlled the synthesis of chlorophyll. On the other hand, Chlorophyll- $a$ per dry weight increased directly with the growth rate until dilution rate of $0.96 \mathrm{~d}^{-1}$ (Fig 3b). This may be a result of the decreasing dry weight per cell not the change of the chlorophyll- $a$ content per cell.

The MONOD model provides more realistic estimate of the maximum growth rate of this species. The maximum growth rate was estimated from the MONOD equation (Fig. 5 ). The maximum growth rate we obtained for $D$. spinosus is one of the highest recorded growth rates in literature (see e.g. REYNOLDS, 1984).

Egypt. J. Phycol. 1, 2000 
During phosphorus controlled growth, a change in the growth rate is accompanied by a change in phosphorous content of the cells and a change in the intracellular distribution of this growth limiting element (DROOP 1983, VELDHUIS \& ADMIRAAL 1987). The $\mathrm{P}$ content of algal cells in phosphorus deficient medium may reach a minimum value below which no further cell division is possible. According to NALEWAJKO \& LEAN (1980), the maximum P-content of one species can exceed the minimum value by an order of magnitude (e.g. 25 time, MACKERETH 1953). This deference varied between 6 and 60 times (JAHNKE et al. 1986). In our experiment, (Qmax) was one order of magnitude higher than (Qmin). The apparent minimum P-content per cell was lower than the calculated value from the DROOP model (Fig.7). In our experiment, the phosphorus content per cell increased with both the dilution rate and the inflowing $\mathrm{P}$ concentration. During P-limitation the cellular phosphorus mobilized for synthesis of cellular phosphorus, such as DNA, RNA and phospholipid, is not dependent upon the external phosphorus concentration, but on the intracellular content. The intracellular pool may control the synthesis of other cellular components and overall metabolism and growth.

During phosphorus controlled growth of $D$. spinosus cellular nitrogen increased linearly with the dilution rate. This behavior is plausible, since $\mathrm{N}$-containing compounds (enzyme, proteins, RNA, etc.) determine the rate of synthetic processes in a linear fashion (FuHS et al. 1972). Cellular $N$ increased especially when the $P$ content per cell increased with the dilution rate.

The growth parameters of $S$. spinosus give an advantage over many other green

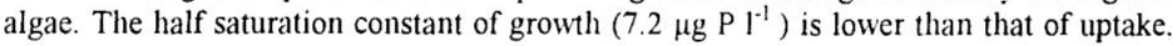
but it is much higher than orthophosphate concentration in Lake Balaton. The concentration of SRP in the lake water is a limiting factor for both the growth and the uptake rate of $S$. spinosus under natural conditions. This may explain why green algae are not dominant in Lake Balaton.

A comparison of growth of Scenedesmus spp. in Lake Balaton and Nile water (MOHAMMED et al 1991), shows that the green algae, which are the dominant group in the Nile system and subdominant in Lake Balaton, are more successful under nitrogen limited than under P limited conditions. This indicate that Scenedesmus spp can not win over other groups (e.g. diatoms) under P limitation, i.e. the Scenedesmus spp. are a good competitors for $\mathrm{N}$ than $\mathrm{P}$.

\section{References}

Ahlgren G., Zeipl K. and Gustafsson I-B. 1998. Phosphorus limitation effects on the fatty acid content and nutritional quality of a green alga and a diatom. Verh. Int. Ver. Theor. Angew. Liminol/Proc. Stuttgart 26:1659-1664.

An S. S., Friedi T. and Hegewald E. 1999. Phylogenetic relationships of Scenedesmus and Scenedesmus-like coccoid green algae as inferred form ITS-2 rDNA sequence comparisons. Plant Biol. 1:418428.

Cepák W. and Lukavský J. 1998. Behavior of chloroplast nucleoids in Scenedesmus obliquus during the vegetative cycle and under nitrogen starved conditions. Arch. Hydrobiol (Algol Stud.) 126:117-127

Egan P. F. and Trainor F. R. 1989. The effect of media and inoculum size on the growth and morphological development of Scenedesmus communis HEGEW (Chlorophyceae) in culture. Arch. Hydrobiol. 117: 77-95 
Elliott R. J. and Porter A. G. 1971. A rapid cadmium method for the determination of nitrate in bacon and curing brines. Analyst, London. 96:522-527.

Gutenbrunner S. A., Thalhamer J. and Schmid A. M. 1994. Proteinaceous and immunochemical distinctions between the oval and fusiform morphotypes of Phaeodactylum triconutum (Bacillariophyceae). J. Phycol. 30:129-136.

Hegewald E. 1982. Taxonomic-morphological studies of Scenedesmus isolates from culture collections. Arch. Hydrobiol (Algol. Stud.) 60:375-406.

Hegewald E. 2000. New combinations in the genus Desmodesmus (Chlorophyceae, Scenedesmaceae). Arch. Hydrobiol (AlgoL Stud.) 131:1-18.

Hindák F. 1990. Studies on the Chlorococcal algae (Chlorophyceae). V. Publishing House of the Slovak Academy of Sciences, pp.225.

Iwamura T., Nagai H. and Ishimura S. 1970. Improved methods for determining content of chlorophyll, protein, ribonucleic acid and deoxyribonucleic acid in planktonic populations. Int. Revue ges. HydrobioL 55:131-147.

Kessler E., Schäfer M., Hummer C., Kioboucek A. and Huss V. A. R. 1997. Physiological, biochemical and molecular characters for the taxonomy of the subgenera of Scenedesmus (Chlorococcales, Chlorophyta). Bot. Acta. 110:244-250.

Langowska I. and Zawadzki Z. 1979 Effect of the kind of illumination on growth of Scenedesmus obliquus (Sc.449). Pol. Arch. Hydrobiol. 26:257-266.

Latasa M. and Berdalet E. 1994. Effect of nitrogen or phosphorus starvation on pigment composition of cultured Heterocapsa sp. J Plankton Res. 16:83-94.

Lürling M. 1999. Grazer-induced coenobial formation in clonal cultures of Scenedesmus obliquus (Chlorococcales, Chlorophyceae). J Phycol. 35:19-23.

Lürling M. and Beekman W. 1999. Grazer-induced defenses in Scenedesmus (Chlorococcales: Chlorophyceae): coenobium and spine formation. Phycologia. 38:368-376.

Lürling M. and Van Donk E. 1999. Grazer-induced colony formation in Scenedesmus acutus (Chlorophyceae): Ecomorph expression at different temperatures. J. Phycol. 35:112 1126.

Lürling M. and Van Donk E. 2000. Grazer-induced colony formation in Scenedesmus: are there costs to being colonial? Oikos 88: 111-118.

Mackereth F.Y.H. 1953. Phosphorus utilization by Asterionella formosa. J Erp. Bot. 4:296-313.

Mladenov R. and Furnacizieva S. 1997. Morphological variability of the colonial cultures of Scenedesmus pectinatus Meyen. Arch. Hydrobiol (Algol. Stud). 118:113-121.

Mladenov R. and Furnadzieva S. 1999. Ontogenetic changes in clonal cultures of Scenedesmus acuminatus (Lagerh.) Chod. and Scenedesmus pectinatus Meyen Arch. Hydrobiol (Algol. Stud). 127:35-46.

Mohammed A. A., Ahmed A. M. and Shafik H. M. 1991. Effect of nitrogen limitation on growth of Ankistrodesmus falcatus and Scenedesmus obliquus. Arch. protistenked. 139 :261-273.

Oliver S. G. 1996. From DNA sequence to biological function. Nature. 379:597-600.

Monod J. 1942. Recherches sur la croissance des cultures bactériennes. Herrmann et Cie. Paris. pp. 210

Morales E. A. and Trainor F. R. 1999. Phenotypic plasticity in Scenedesmus: implications for algal taxonomy and ecology. Gayana Bot 56:77-86.

Murphy J. and Riley J. P. 1962. A modified single solution method for the determination of phosphate in natural waters. Analytica chim. Acta 27:31-36.

Nalewajko C. Colman B. and Olaveson M. 1997. Effects of pH on growth, photosynthesis, respiration, and copper tolerance of three Scenedesmus strains. Environ. Erp. Bot. 37:153160.

Pawlak B. and Kopec J. 1998. Size distribution of Scenedesmus obliquus cells: experimental results from optical microscopy and their approximations using the phi -normal distribution. Oceanologia. 40: 34 354.

Reynolds C. S. 1991. The ecology of freshwater phytoplankton. Cambridge studies in Ecology Cambridge University, pp. 384

Egypt. J. Phycol. 1, 2000 
Rhee G-Y. 1973. A continuous culture study of phosphate uptake, growth rate and polyphosphate in Scenedesmus sp. J Phycol 9:495-506.

Rhee G-Y. 1978. Effects of N:P atomic ratios and nitrate limitation on algal growth, cell composition, and nitrate uptake. Linmol. Oceanogr, 23: 10-25.

Ridly M. 1996. Evolution. Second edition. Blackwell Science, Cambridge, Massachusetts USA. pp.719.

Sancho M. E. M., Castillo J. M. J. and El Yousfi F. 1997. Influence of phosphorus concentration on the growth kinetics and stoichiometry of the microalga Scenedesmus obliquus. Process Biochem. 32:657-664.

Saritorn V., Beilni C. and Caboche M. 1994. Use of two-dimensional protein-pattern analysis for the characterization of Arabidopsis thaliana mutants. Planta.192:557-566.

Shafik H. M. 1985. Growth of some Nile phytoplankton algae in continuous culture. M.Sc. Thesis. Assiut University, Egypt. pp.85.

Shafik H.M. 1991. Growth, nutrient uptake and competition of algae of Lake Balaton in flowhrough cultures Ph.D. Thesis, Hungarian Acadeny of Sciences, Tihany. pp.144.

Siver P. and Trainor F. R. 1981. Morphological control and physiology of Scenedesnus strain 170. Phycologia. 20:1-11.

Siver P. and Trainor F. R. 1983. Effect of growth rate on unicell production in two strains of Scenedesmus (Chlorophyta). Phycologia. 22:127-131.

Sorokin C. and Krauss R. 1958. The effects of light intensity on the growth rates of green algae Plant Physiol. 33:109-113.

Tezuka Y.1977. The effect of nutrient concentration on the standing crop of Scenedesmus obliquus grown under continuous culture condition. Jap. J. Limmol. 38: 90-93.

Thibault Y. and Couture R. 1982. Effects of Temperature on the Growth of 2 Green Algae of the St-Laurence River, Gentilly Sector, Quebec. Hydrobiol. 88:309-318.

Tilma D., Kilham S. S. and Kilham, P. 1976. Morphometric changes in Asterionella formosa colonies under phosphate and silicate limitation. Linmol. Oceanogr. 21:883-886.

Trainor F. R. 1979. Scenedesmus AP 1 (Chlorophyceae): polymorphic in the laboratory but not in the field Phycologia. 18:273-277

Trainor F.R. 1991. The he format for a Scenedesmus monograph Arch. Hydrobiol (AlgoL Stud). 61:47-53.

Trainor F. R. 1992 a. Cyclomorphosis in Scenedesmus armatus (Chlorophyta): An ordered sequence of ecomorph development J. Phycol. 28:553-558.

Trainor F. R. 1992 b. Cyciomorphosis in Scenedesmus communis Hegrew. Ecomorph expression at low temperature. Br Phycol. J. 27:75-81.

Trainor F. R. 1993 a. Cyclomorphosis in Scenedesmus subspicatus (Chlorococcales, Chlorophyta) Stimulation of colony development at low temperature. Phycologia. 32:429433.

Trainor F. R. 1993 b. Cyclomorphosis in Scenedesnus subspicatus R. Chod. cell behavior during the unicell-colony transformation of a phenotypically plastic organism. Arch Protistenkd. 143:55-61.

Trainor F. R. 1995. The sequence of ecomorph formation in a phenotypicly plastic, multispined Scenedesmus species (Chlorophyceae). Arch. für Hydrobiol. 133:161-171.

Trainor F. R. 1996. Reproduction in Scenedesmus. Algae 11:183-201.

Trainer F. R., Cain J. and Shubert L. 1976. Morphology and nutrition of the colonial green algae, Scenedesmus:80 years later. Botanical Review 42:5-25.

Uherkovich G. 1995. The green algal genera Scenedesmus (Chlorococcales, Chlorophyceae with special attention to taxa occurring in Hungary). (Ed. Kiss K.T.) Hungarian National museum press, Budapest. pp. 234

Utermöhl H. 1958. Zur Vervollkommnung der quantitativen Phytoplarikton-Methodik. Mitt. Int Verein. Limnol. 9:1-39. 
Veldhuis M. J. W. and Admiraal W. 1987. Influence of phosphate depletion on the growth and colony formation of Phaeocystis pouchetii. Mar. Biol. 95:47-54.

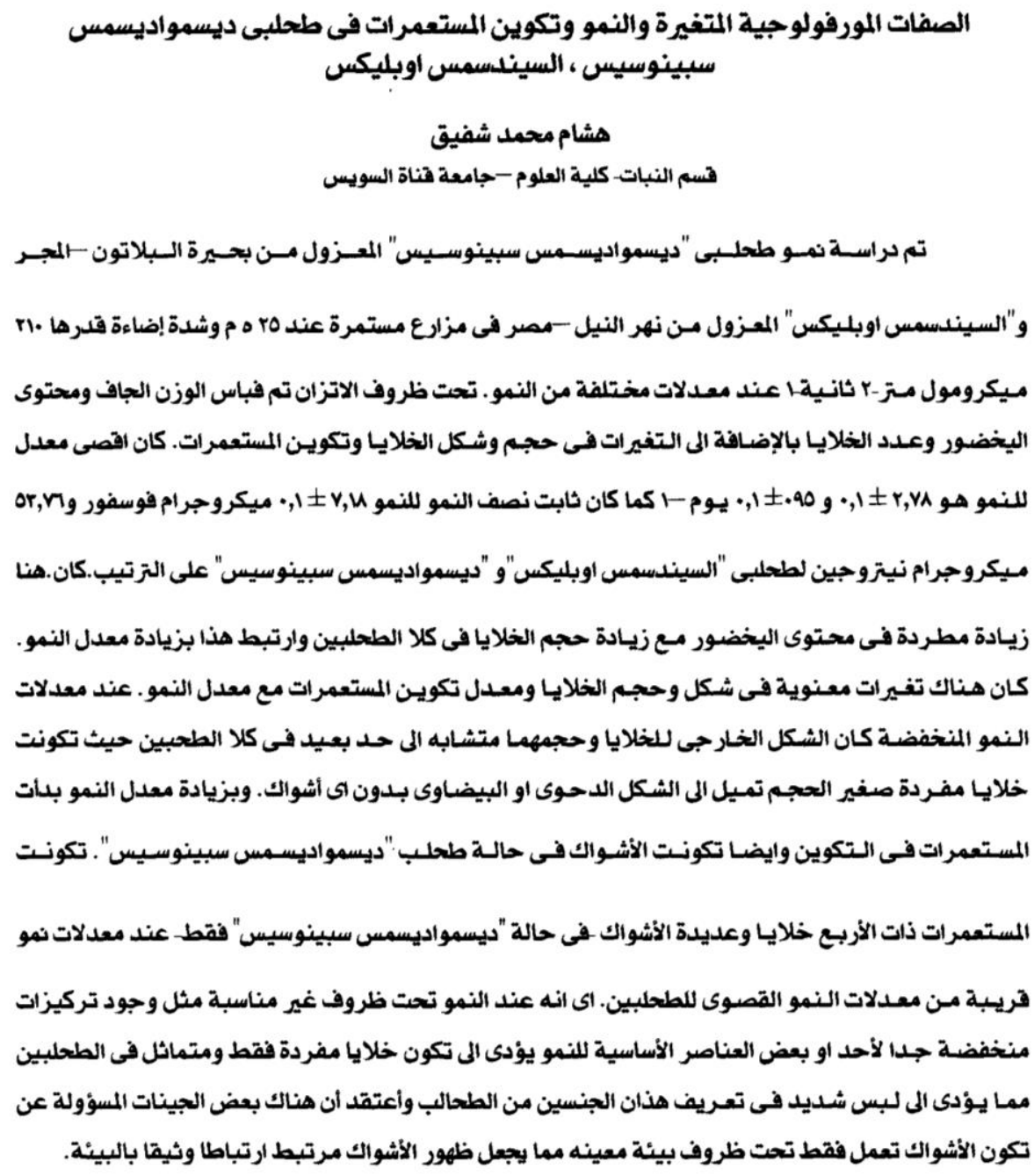

